\title{
Nusekh Poyln and the 'New Jewish Man'. The Image of the Jewish Communist in Yiddish Literature of Post-War Poland ${ }^{1}$
}

\author{
Magdalena Ruta \\ (Jagiellonian University, Krakow) \\ e-mail: dlamagdaleny@gmail.com
}

Key words: Yiddish literature, Communism, postwar Poland, the Holocaust, 'new Jewish man', Socialist Realism

\begin{abstract}
After World War II, the Communist regime took over power directly after the liberation of Poland in 1945. Jewish survivors, having stayed in the country for a certain period of time, tried to revive their multilingual cultural life. Literary works of writers in that community are a fascinating testimony of their struggles: how to be loyal to the Socialist state (condition sine qua non to take part in the official cultural life) on the one hand, and on the other how to express their feelings, thoughts and convictions which they could not and did not want to ignore. Their struggles can be observed on the sample of the three most important motifs of postwar Polish-Yiddish literature: the Holocaust, Communism itself, and Polish-Jewish relations. The article discusses selected literary works of the most prominent Polish-Yiddish writers, whose main character or lyric subject is the 'new Jewish man' shaped according to the Communist principles. The author attempts to answer the question of what the most important features of a personality formed by Communist doctrine are, and also to learn about the circumstances of the communist world in which that literary hero lives. Close reading of the programmatic literary pieces of some Communist writers also enables observing whether and how Polish Jewish Communists managed to find a compromise between the mutually exclusive Communist internationalism and their attachment to Yiddish-language culture, and how they reacted when information of Stalinist crimes came to light and their party comrades turned the blade of antisemitism against them. The ambitious project to build a new model of secular progressive Yiddish culture (the so-called 'nusekh Poyln'), failed to bring the expected results. In spite of concerted attempts to meet the unrealistic demands of Socialist Realism, it soon transpired that Polish-Yiddish literature under Communism was unable to deal with the lack of space afforded by Communist ideology for mourning its murdered nation or with the spasms of unease that were the reaction to the periodic antisemitism in the non-Jewish environment.
\end{abstract}

\footnotetext{
${ }^{1}$ The article is based on fragments of Magdalena Ruta's book Without Jews? Yiddish Literature in the People's Republic of Poland on the Holocaust, Poland and Communism, transl. J. Taylor-Kucia, Kraków: Jagiellonian University Press, 2017.
} 
In Poland, in which communists took over power after World War II, a relative freedom in socio-political and cultural life prevailed in the initial post-war years, 19451949 , despite the radical political change. ${ }^{2}$ These five years were also a time of intense migration of Jewish survivors, who came back from concentration camps, emerged from hiding, or returned from the Soviet Union and left the country after a short period of time. In the middle of 1946 there were about 240,000 Jews in the country, ${ }^{3}$ and in 1949 only 100,000. ${ }^{4}$ That year marked the end of the period of relative freedom, and the beginning of the Stalinism era, which lasted until 1956, when the political thaw began. Among about 80 writers who were in Poland at that time there was a group of literati more or less involved in communism. Most of them remained in the country for a certain period of time and constituted a relatively stable core of post-war literary life. These names merit mention here: Lili Berger, Yitskhok Guterman, Binem Heller, Simkhe Kants, Leyb Morgentoy, Leyb Olitski, Elye Rayzman, Hadase Rubin, Kalman Segal, David Sfard, Moyshe Shklar, Shloyme Strauss-Marko, Paltiel Tsibulski, and Yankev Zonshayn.

Until 1949 no rigorous postulates were formulated as to what should constitute 'progressive' Yiddish culture; it was only at the congress of the Jewish Culture Society in October 1949 that Socialist Realism was pronounced as the officially binding creative method. ${ }^{5}$ Yiddish culture was to be 'national in form, socialist in content,' and its Jewishness limited to Yiddish language and to selective referencing of Jewish traditions and history. The aim of Jewish Communists was to create a new progressive Yiddish culture, and - in effect - a new Jewish identity. The salient characteristics of the "new Jewish man' were activeness, a high level of industrial productivity, work for the community, and teamwork in the cause of his class; secondary to those was the cause of his nation. Further attributes of the new, ideal Jew were supposed to be: fighting not only antisemitism but above all social injustice; identifying with the international struggle for peace, socialism and the liberation of colonial populations; faithfulness to the socialist Polish state; fluency in the Polish language, history and literature; and - last but not least - atheism. ${ }^{6}$ This new model of Jewishness was the antithesis of the traditional model that had been dominant in the pre-war shtetl. The aim of this article is to briefly reconstruct the image of the 'new Jewish man' in literary works of Polish-Yiddish writers with some links to communism.

Execution of the communist programme came up against problems from the outset. In the initial years after the war in particular (although later as well) a major hurdle was the memory of the Jewish national tragedy. Until 1948 the Jewish Communists pursued their policies under the banner of national unity. ${ }^{7}$ This momentary 'softening' of the dogmatic position, which on the wave of the extreme degree of the nation's mourning

\footnotetext{
${ }^{2}$ On Yiddish cultural life in postwar Poland see Nalewajko-Kulikov, Ruta 2014: 327-352.

${ }^{3}$ Stankowski 2014: 212.

${ }^{4}$ See Berendt 2008: 759 .

${ }^{5}$ See Zjazd Żydowskiego Towarzystwa Kultury w Polsce 1950 (in Polish); Tsuzamenfor fun der Yidisher Kultur-Gezelshaft in Poyln 1949 (in Yiddish).

${ }^{6}$ On the general characteristics of a new Jewish man according to Jewish communists in Poland see Grabski 2004: 46.

${ }^{7}$ Ibid.: 43.
} 
permitted solidarity with all victims of the Holocaust, is evident in the literature being written above all during and immediately after the war. A return to a black-and-white worldview ensued at the end of the 1940s. In this period literary criticism redoubled its calls for a focus on the new socialist reality, and its hero above all. And while most writers did their best to rise to the challenge, not all proved capable of meeting the ideologues' demands. Things changed again with the political thaw of 1956.

The main literary figure of that time was Binem Heller, whose poetry was proclaimed the model of Socialist Realist literary output. His early, pre-war, works are protest poems speaking out on behalf of the masses. The lyrical subject of his poetry is a communist with a strong bond with the Jewish nation, and his progressive, democratic Jewishness is defined in opposition to traditional yidishkeyt. Proponents of the old world are called upon by him to make way for the young, who want to change the world. As early as in 1932, Heller writes in the poem Skeynim [Old Men]: ${ }^{8}$

The old people are sailing away to the country of old age -

On the mouldy, fissured ships of faith;

All their zeal turned to ash long ago,

And the love in their hearts has gone cold.

Like Kiddush cups their eyes full

Of cloudy tears - raisin wine.

Their acuity is gone, with their youth,

And the blood has dried in their veins.

$[\ldots]$

They are preparing for the road to a bright paradise,

Swallowing the yellowed pages of the psalms in the evenings,

And it is as easy for them to say farewell to the world

As the last prayer that leaves their mouths. ${ }^{9}$

The young Jewish Communists were also radical in their rejection of anything that distracted them from their goal. In the work Kh'bin nisht gevoynt [I am Not Accustomed], ca. 1950, Heller sums up thus the great effort that had to be made by the young Jews who devoted their lives to Communism:

I was dogged by the melancholy shades

Of past generations of God-fearing Jews.

With their lament they tried to force me

To carry their heritage on.

$[\ldots]$

${ }^{8}$ This poem from 1932 resounds with echoes of the 1924 work 'Fargeyt ir umetike zeydes...' by Soviet-Yiddish poet Izi Kharik, whose subject distances himself from the generation representing the traditional Jewish world. This similarity can be interpreted as an influence of Soviet-Yiddish poetry on literature of Polish-Yiddish Communist writers. More on Kharik's poem see Shneer 2004: 193-194.

${ }^{9}$ Heller, Skeynim, in: idem 1956: 32. 
I tore it all out of myself,

Inflicting on myself wounds so dear to me.

And though I bled, with the new generation

I resolved to bind my life. ${ }^{10}$

Interestingly, the portrayal of a pre-war communist in the novel Dodye Koval, ${ }^{11}$ published in 1951 by the "nestor of Polish-Yiddish literature", before WW II identified with the Bund, Leyb Olitski, is different from that of Heller. The novel's narrator is a witness to the transformation undergone by the community of pre-war shtetl as a whole, and the growth to maturity of selected characters, among them the eponymous smith Dodye Koval and his son Itsik, the communist, who are merely personifications of this transformation. The narrator's viewpoint runs concurrent to Socialist Realist guidelines on many points, but communism is portrayed as one of many political options with which young Jews identify. And although from the outset, when proponents of communism enter the story, the narrator signals that Communism is allegedly the best ideological option; he makes no consistent parallel effort to undermine the significance of other ideologies. Behind the Socialist Realist façade there seems to be an ambivalence that prevented the author from fully conforming to the doctrinal requirements.

Another chapter in a literary biography of a Jewish Communist describes works from 1939-1941, when the eastern part of Poland was annexed to the Soviet Union. For some Polish-Jewish refugees that time was a respite from the cruelty of war, but it was also a time of painful confrontation with the order imposed by the Soviet authorities. For those with links to Communism it was a time of intellectual revival, when they could write and be published. Post-war Polish-Yiddish literature, under surveillance of communist censorship, records above all the positive aspects of Soviet reality. Heller called the time between 1939-1941 the new era of freedom he and every Jewish Communist had dreamed of, the freedom which inspired him, releasing energy and activity.

The initial delight at that freedom was nevertheless undermined by unease at what was happening to Jews in Poland. Very few of the poems from that period, when Germany was an ally of the Soviet Union and criticism of Germany was frowned upon, contain even echoes of fears for loved ones who stayed in German occupied territory, and those works that do are mostly by Heller. ${ }^{12}$ The fate of Jews in occupied Poland is not articulated directly; the word 'Germany' is not mentioned once, as in the work Ikh bin do [I am Here], written in 1939 in Białystok:

${ }^{10}$ Heller, Kh'bin nisht gevoynt, in: idem 1951: 70-71.

${ }^{11}$ Olitski 1951a.

${ }^{12}$ Among the poems published in post-war Poland, I found only two works (furnished with the information that they had been written in 1941) which spoke less legibly still than those by Heller of missing loved ones who had remained somewhere far away, and about their probable death or danger to their life. These are 'A briv tsu tatn' by Gute Guterman, from the volume Der opgrunt roysht, Varshe: Yidish Bukh, 1948: 5-7, and $A$ briv fun mayn mamen by Volf Herhs Ivan, from the volume Oyf heymisher erd, Varshe: Yidish Bukh, 1950: 21-22. 
Now all that [Warsaw] is far away,

The long kilometres fade in the fog.

A crow flies from there squawking:

The leaves of yellow patches are falling!

Small Jews bent double

Are taking them with them.

Small Jews - in place of eyes

Deep holes full of fear. $---{ }^{13}$

In these few lines the poet encompasses the meagre information that has reached him: his compatriots are forced to wear yellow patches, their lives have been turned into a nightmare, and many of them have been shot. This concealed worry is betrayed by the titles of poems from successive years: Mayn mame in geto ${ }^{14}$ [My Mother in the Ghetto] of 1940, and Opklang fun duner ${ }^{15}$ [The Sound of Thunder] of 1941, in which he reveals the sharp contrast between the peaceful life on the Soviet side of the Bug River, and the fate experienced by the Jews in German-occupied Poland. In one of these works he asserts that although today he is silent, in the future he will avenge the suffering of his mother, who in his war poems is often employed as a figure representing the entire nation.

Knowledge of the fate of the Polish Jews during WW II Poland helped to strengthen the bonds between communist survivors in the Soviet Union and all members of the nation, irrespective of their worldviews. The central characters/lyrical subjects of many literary texts from this war period are aware that they are some of the last Jews and thus have a duty to preserve the memory of the dead and a responsibility to rebuild the destroyed world. ${ }^{16}$ Heller writes in the poem Khorev [Ruin]: "It has been adjudged to my blood to be a guardian of the memory / of all - tailors, butchers, / beggars, singers, porters, / husbands with hurried gestures, — / noble, virtuous wives [...]." ${ }^{\prime 17}$ This and his other war poems convey the feelings of many survivors who were aware that they owed their lives to the Soviet state. He admits that it was the communist ideology of fighting for a new world that had renewed the mentality of Polish Jews, as he writes in the poem Ikh, der letster [Me, the Last One], 1942:

Of my whole family only I remain

On this earth shaken by convulsions.

And though I have bathed in fire and blood,

I live the life granted me here.

[...]

${ }^{13}$ Heller, Ikh bin do, in: idem 1948: 42.

${ }^{14}$ Heller, Mayn mame in geto, in: ibidem: 86-87.

${ }^{15}$ Heller, Opklang fun duner, in: ibidem: 88-89.

${ }^{16}$ See, for instance, the short story by Shloyme Berlinski 1946: 35-38, and the poems of Binem Heller Glik, Ikh, der letster, in: idem 1948: 122, 125.

${ }^{17}$ Heller, Khorev, in: ibidem: 184. 
My brothers exterminated, my mother dead -

Death is part of my life.

But know - not for nothing has my hand gripped

The earth and the standard that burn red!

It is here that I, the last, have been granted a beginning -

So, faithful to my nation,

I shall restore light and life

To all that which is gone in blood. ${ }^{18}$

In the initial post-war years, literature rejected concentrating primarily on current issues and (supposedly) positive political transformations taking place in Poland, which, according to the communist authorities, should have been its main goal. It was so because the recent Holocaust and the Polish antisemitism had dominated the writing published in the press and literature of the period. After the 1949 Wrocław Congress, where a new programme for Jewish culture was proclaimed (known as Socialist Realism), the Jewish strands were first drastically reduced to the bare Communist minimum, and then extensively instrumentalized. ${ }^{19}$

The largest and most diverse group of Socialist Realist writings comprises works of poetry dealing with typical strands and themes of that period: panegyrics to Stalin, Bierut, the USSR, and the Red Army; praise of the new reality, industrialization, production processes, the competitive work ethic, and the civilizational transformations testifying to human genius and might; texts apotheosizing youth and laying bare the class enemy; poems about peace; and in and after 1953, elegies on Stalin's death. This part of Socialist Realist writings constitutes slightly over fifty percent of all the poetry from 1949-1955. The same cannot be said of Socialist Realist prose in Yiddish. Not a single 'productivist' novel was written, and the only Socialist Realist novella, Oyslendishe valiute ${ }^{20}$ by Leyb Olitski in 1951, was heavily criticized by a reviewer for the regime. In spite of a trend towards unification striving to eliminate the ethnic difference of the Jews, specifically Jewish themes are still in evidence - the two prime Jewish threads of this period are the Holocaust and the portrait of the 'new Jew.'

The first literary assays at creating a 'new Jewish man' were attempted by Heller and Olitski. One aspect, characteristic for Heller's entire oeuvre, is his constant emphasis on both dimensions of his self-identification: the Jewish and the Communist. The many poems in which he makes reference to the Holocaust are not merely a tribute to the dead, but are above all an expression of authentic mourning for his immediate family and the whole Jewish nation. At the same time, this personal pain gives the lyrical subject the right to use the theme of the Holocaust for propaganda purposes, as in pacifist poems such as Tsu Pol Robson [To Paul Robson ${ }^{21}$ ], ca. 1951, whose subject comes out in solidarity with 'the blacks interned in the ghetto of black skin.' Jews and

\footnotetext{
${ }^{18}$ Heller, Ikh, der letster, in: ibidem: 125.

${ }^{19}$ More on Socialist Realism in Yiddish literature see: Nalewajko-Kulikov 2006: 171-177.

${ }^{20}$ Olitski, Oyslendishe valyute, in: idem 1951b: 5-91.

${ }^{21}$ Paul Robson, an American vocalist with Communist sympathies and a critic of USA government policy.
} 
blacks, united by their shared experience of marginalization and stigmatization, together sing the hymn of the fighting ghetto, which presages the advent of the hour of liberation. It is unnecessary to add that Heller portrays in his works a skewed vision of history, appropriating the memory of the ghetto uprising for the Communists.

The lyrical voice of Heller's poetry is the embodiment of the recommendations issued by the party ideologues. The same cannot be said of the character created by Olitski in the 1951 novella Oyslendishe valiute. In this latter case, the choice of hero is untypical: Shmuel Kovenski is a teacher, and as such a member of the Jewish intelligentsia. While he seems to support the transformations taking place in post-war Poland, the temptation to enrich himself by speculating in a foreign currency causes us to see in him a representative of the old times, one who thinks only of himself. The example of his wife, who is an ardent communist, however, or perhaps the fear of punishment for concealing illegal money, brings about a change within him, and he ultimately abandons his shameful plans and confesses his sins to his wife. Eventually he wants to join the communist party. His wife forgives him, but the reader begins to wonder how far his metamorphosis is a consequence of positive changes to his worldview. The critic Michał Mirski accused Olitski of an ideological immaturity that prevented him from writing appropriately about the "new man.' 22 In fact, the portrait of Kovensky as a future communist seems to suggest Olitski's ambivalence toward communism.

The most radical attempt to create a model hero for the new times in prose was made by Simkhe Kants in his 1952 short story In fabrik ${ }^{23}$ [In the Factory], the second (after Olitski's novella) of three longer prose works written according to the principles of Socialist Realism. The representative of the modern Jewish worker community integrated with the Poles is Natan Levinger - an ideal 'new Jewish man'. In line with the programme of the Jewish Communists, the author does not emphasize the ethnic differences between Poles and Jews. The narrator mentions only a few times that the Jewish characters use a different language. One such passage is given here, in which the narrator is looking out of the window at the darkening alleyway down below:

I looked at the illuminated windows. At the bottom they were crowded with flowers, and at the top swathed in flowery curtains. In the evenings the sounds of a piano could often be heard from that direction. That was the home of Wigdorowicz from the tailor co-operative, a hefty man with palish skin. His wife, a blonde with pretty bright eyes, is also plump. They walk to the tram together in the early mornings. It is their ten-year-old son who plays the piano. The sound of songs being sung in Yiddish can also often be heard. I thought:

'This is how beautiful the life of workers living in a socialist country is. ${ }^{24}$

It is worth emphasizing the extent of Kants' unifying efforts - Jews are not differentiated from Poles even by their tragic past. There is not a single word about the Holocaust in the story, and the war is mentioned only once, and then in such an allusive manner that its significance is entirely marginalized.

\footnotetext{
${ }^{22}$ Mirski 1952.

${ }^{23}$ Kants, In fabrik, in: idem 1952: 7-89.

${ }^{24}$ Ibid.: 16.
} 
The identity of the 'new Jewish man' crafted by Yitskhok Guterman in the 1954 short story Dos lebn hot im gerufn ${ }^{25}$ [Life Called Him] is different again. The main character is Meir Mendelevitsh, a weaver and pre-war trade union activist who, by fleeing to the Soviet Union, was the only member of his family to survive. When he learns, on his return to Poland, that none of his loved ones are still alive, he retreats in resignation to an old people's home. He wallows in despair and allows himself to be consumed by mourning. Nevertheless, as time goes by, Mendelevitsh starts to feel slightly better, and gains strength and vitality. He starts to look around for some work. This old man, with his traumatic experiences behind him, regains his equilibrium thanks to the socialist state's provision for his basic needs, and the ubiquitous, enthusiastic atmosphere surrounding work for the common good has a stimulating effect on him. There is thus hope that all Poles will feel called by life itself to follow in the footsteps of those who are building the new Poland, and in the case of old Jews, the process of positive change is not hampered even by their mourning.

The political thaw in Yiddish literature officially began in 1956. Yiddish culture attempted retribution for the previous period and opened up to all things new. Jewish artists, seeking answers to the question of their identity in the new times, returned to themes related to their nation, giving more direct expression to their pain at the death of millions Jews in the Holocaust, or moving away from instrumental treatment of it, and expressing an interest in traditional Jewish culture, contemporary Israeli culture, and the work of Soviet writers. The retributive current was restricted to the poetry, and it was a kind of confrontation with the poets' own ardent, blind faith in the dogmas of communism and with their disillusionment following the collapse of its foundations. ${ }^{26}$ In prose it tended to be exemplified more by an overall change of theme and a return to exploration of traditional strands in Jewish literature, such as the image of the shtetl. ${ }^{27}$ Another important element of this current is protest against the antisemitism in the communists' ranks, and in Polish society.

Yet a greater impression still than the antisemitism of their party comrades was made by the news of the tragic deaths of the Soviet-Yiddish writers Itsik Fefer, Perets Markish, Dovid Hofshteyn, Leyb Kvitko and Dovid Bergelson, which reached Polish Jews about 1955-1956. ${ }^{28}$ It was Binem Heller who devoted the most space to the memory of his fellow poets murdered in 1952. This tragedy certainly became another constituent element of the Jewish identity of the lyrical subject in his poems. In the poem Der toyt funem zinger [The Death of the Poet], in 1955, he draws attention to the anti-Semitic subtext of this crime, which came so unexpectedly:

The poet was led out to death,

His eyes were blindfolded with a rag,

${ }^{25}$ Guterman, Dos lebn hot im gerufn, in: idem 1954: 7-63.

${ }^{26}$ On retribution poetry of Hadasa Rubin, the only Yiddish poetess in postwar Poland, see: Ruta 2015: $208-229$.

${ }^{27}$ See Ruta 2009: 129-144.

${ }^{28}$ More on the editorial Undzer veytik un undzer treyst published on 4 of April 1956 in Folks-Shtime (the Yiddish-language press organ of the Communist Party in Poland, PZPR) where the news about the death of Soviet-Yiddish writers was published for the first time, see Estraikh 2008: 218-223. 
His hands bound with a cord,

A volley — and he disappeared into the abyss.

He wanted to ask about something,

For there is more bewilderment than fear in death.

But the earth before him was alien

And would not understand his Jewish tongue. ${ }^{29}$

During the political thaw of 1956 and thereafter the theme of a 'new Jewish man' disappeared from the Yiddish literature published in post-war Poland. Later, in the 1950s and 1960s, it was present only in memoirs devoted to the revolutionary youth of their authors, such as Shloyme Strauss-Marko's Geven amol a shtetl. ${ }^{30}$

At the beginning of 1957 Binem Heller left Poland for Israel. A few years later Hadase Rubin followed him, but the fate of the others was only decided in the later part of the next decade. The nusekh Poyln project, with its aim to develop secular progressive Yiddish culture and literature, finally collapsed with the outbreak of the witch hunt against the Jews in 1967-1968, which led to the emigration of more than 13,000 people, among them David Sfard, Kalman Segal, Shloyme Strauss-Marko, and Moyshe Shklar.

\section{BIBLIOGRAPHY}

\section{Primary sources (selection)}

Berlinski, S. (1946), Di Yelins, in: Yidishe shrift. Literarish zamlbukh, Lodz: 35-38.

Guterman, G. (1948), Der opgrunt roysht, Varshe.

Guterman, I. (1954), Dos lebn hot im gerufn, in: idem, Banayte teg, Varshe: 7-63.

Heller, B. (1948), Durkh shotn un shayn, Varshe.

Heller, B. (1951), Heymerd, Varshe.

Heller, B. (1956), Dos ershte lid, Varshe.

Heller, B. (1957), Klorkeyt, Varshe.

Ivan, V.H. (1950), Oyf heymisher erd, Varshe.

Kants, S. (1952), In fabrik, in: idem, Naye teg, Varshe: 7-89.

Olitski, L. (1951a), Dodye Koval, vol. 1-3, Varshe.

Olitski, L. (1951b), Oyslendishe valyute, in: idem, Mentshn in klem, Varshe: 5-91.

Strauss-Marko, S. (1965), Geven amol a shtetl, Varshe.

\section{Secondary sources}

Berendt, G. (2008), Zamiast przypisów: Informacje przydatne w lekturze opowieści bohaterów książki, in: J. Wiszniewicz, Życie przecięte. Opowieści pokolenia Marca, Wołowiec: 759.

Estraykh, G. (2008), Yiddish in the Cold War, Oxford.

Grabski, A. (2004), Działalność komunistów wśród Żydów w Polsce (1944-1949), Warszawa.

Mirski, M. (1952), Vegn L. Olitskis „Mentshn in klem”, Idishe Shriftn, no. 3.

\footnotetext{
${ }^{29}$ Heller, Der toyt funem zinger, in: idem 1957: 7.

${ }^{30}$ Strauss-Marko 1965.
} 
Nalewajko-Kulikov, J. (2006), Czy socrealizm miat odmianę żydowska? Kilka uwag o twórczości pisarzy jidysz w powojennej Polsce, in: K. Stępnik, M. Piechota (eds.), Socrealizm: Fabuły - komunikaty-ikony, Lublin: 171-177.

Nalewajko-Kulikov, J., Ruta, M. (2014), Yiddish Culture in Poland after the Holocaust, in: F. Tych, M. Adamczyk-Garbowska, (eds.), Jewish Presence in Absence: The Aftermath of the Holocaust in Poland, 1944-2010, Jerusalem: 327-352.

Ruta, M. (2009), A Tale of the Murdered Shtetl: The Image of the Shtetl in Yiddish Literature in Post-war Poland, European Judaism: A Journal for the New Europe, vol. 42, no. 2: 129-144.

Ruta, M. (2015), The Earth Hurts Me: On the Poetry of Hadasa Rubin, in: R. Horowitz (ed.), The Legacy of Yiddish Woman Writers, Jefferson, NC: 208-229.

Ruta, M. (2017), Without Jews? Yiddish Literature in the People's Republic of Poland on the Holocaust, Poland and Communism, transl. J. Taylor-Kucia, Kraków.

Shneer, D. (2004), Yiddish and the Creation of Soviet Jewish Culture, 1918-1930, Cambridge.

Stankowski, A. (2014), How Many Polish Jews Survived the Holocaust, in: F. Tych, M. Adamczyk-Garbowska (eds.), Jewish Presence in Absence: The Aftermath of the Holocaust in Poland, 19442010, transl. G. Dąbkowski, J. Taylor-Kucia, Jerusalem: 212.

Tsuzamenfor fun der Yidisher Kultur-Gezelshaft in Poyln, Wroclaw 14-16 X 1949, 1949, Warszawa (in Yiddish); Zjazd Żydowskiego Towarzystwa Kultury w Polsce. Wrocław 14-16 października 1949, 1950, Warszawa (in Polish). 